\title{
METHODOLOGY OF FORMING MODEL FOR ASSESSING THE LEVEL FINANCIAL SECURITY
}

\author{
Oleksandr Sylkin ${ }^{1}$, Myroslav Kryshtanovych ${ }^{2}$, Yuliya Bekh ${ }^{3}$, Oleksandr Riabeka ${ }^{4}$ \\ ${ }^{1}$ Doctor of Philosophy, Department of Financial and Economic Security, Accounting and Taxation, \\ Ukrainian Academy of Printing, Pid Golosko str. 19, 79000, Lviv, Ukraine. \\ Phone Number+380677933153, Email Addressdrvel@ukr.net \\ ${ }^{2}$ Professor,Lviv Polytechnic National University, Bandery str. 12, 35000, Lviv, Ukraine. \\ Phone Number+380677933153, Email Addressmf0077@ukr.net \\ ${ }^{3}$ Doctor of Philosophy, National Pedagogical Dragomanov University, Pyrogova str. 9, 01601, \\ Kiev, Ukraine. Phone Number+380677933153, Email Address yu.v.bekh@i.ua \\ ${ }^{4}$ Doctor of Philosophy, National Pedagogical Dragomanov University, Pyrogova str. 9, 01601, \\ Kiev, Ukraine. Phone Number+380677933153, Email Addess ryabeka@i.ua
}

Received 0702 2020; Accepted 31082020

A map of a multi-level algorithm for assessing financial security has been developed, the use of which determines the feasibility of applying operational, tactical and strategic anti-crisis measures. It is proved that the effectiveness of anti-crisis measures substantially depends on information support, the formation of which at the proper level is possible when applying the developed model for assessing the financial security of an enterprise. The use in the model of quantitative and qualitative indicators characterizing the main parameters of the financial activity of the enterprise, allows to characterize the level of security and forms the analytical basis for the adoption and implementation of the most appropriate anti-crisis measures. Using an expert assessment, the main indicators for assessing the financial security of the enterprise are identified.

Keywords: security, financial security, assessing, model, enterprise.

JEL Codes: D21, D81, D82, G32.

\section{Introduction}

Ineffective government regulation of the industrial sector, an unbalanced taxation system, a low production infrastructure, a low level of financial planning within the company, an inability to respond quickly to changes in the environment where the company operates are all, and many other problems can create a phenomenon like crisis.

Today in the field of management, the concept of "anti-crisis management" has evolved and is a constant continuous process in the enterprise. But the crisis can not always strike a blow to the entire enterprise, mainly it can concern one of its links: financial, marketing, administrative, production and technological and the like. So, the most vulnerable spot is the financial component of the enterprise. This led to the study of anti-crisis management in the system of ensuring the financial security of the enterprise.

The purpose of the study is to form a model for assessing the financial security of an enterprise with the possibility of applying anti-crisis management.

The object of research is the process of applying anti-crisis management in the system of ensuring economic security of an enterprise.

Copyright (C) 2020. Published by Vytautas Magnus University. This is an open access article distributed under the terms of the Creative Commons Attribution Non-Commercial 4.0 (CC BY-NC 4.0) license, which permits unrestricted use, distribution, and reproduction in any medium provided the original author and source are credited. The material cannot be used for commercial purposes. 
The subject of the study is financial security, anti-crisis management system.

To determine and justify our research, we applied the following methods: induction and deduction, comparison and systematization; synthesis and analysis; morphological analysis; graphic - for a visual representation of theoretical and methodological material; abstract-logical - for theoretical generalizations and conclusions of the study.

\section{Literature review}

In the scientific literature, a large number of mathematicians and economists worked in the direction of assessing the level of financial security of an enterprise, among which: O. Aref'eva, Y. Prokhorova (2008), I. Blank (2005), K. Goryacheva (2003), Yu. Prokhorova (2008), A. Kovalev (1998), A. Plastun (2007), L. Ligonenko (2005), Kh. Mandzinovskaya, A. Shtangret (2016) and others. Despite a sufficient number of studies, unfortunately, they are mainly aimed at assessing the general level of financial security of an enterprise. Today, after the crisis development of the engineering industry, there is a need to study the assessment of the level of financial security, at which it is necessary to apply anti-crisis management.

In international practice and scientific literature, the time has passed to determine when it is necessary to apply anti-crisis management, they used methods to predict the onset of bankruptcy (despite its legal status, bankruptcy remains a phenomenon, it is formed precisely for financial reasons).Today, almost single-handedly, scientists (I. Demchenko 2012), confirm that a large number of bankruptcy forecasting techniques can demonstrate accurate results in the current conditions of the development of the Ukrainian economy, while noting that one of the main reasons is the incorrect mechanical transfer of empirical coefficients to domestic practice and the inability to meet our inflation rates.

It is very difficult to take and apply anti-crisis management. As S. Gasanov, A. Stangret, Y. Kotlyarevsky (2012) have noted, anti-crisis management of an enterprise is a certain sequence of managerial efforts that must be carried out in stages. We partially agree with this, and therefore believe that this kind of process from a technological point of view should be presented in the form of a certain sequence of steps and procedures that have both direct and inverse relationships.

Ali Lami Hyder Muhsin Abdulaziz (2016) considered strategic directions for implementing anti-crisis management for processing enterprises through the dynamics of the opportunities and threats of this type of enterprises. K. Golovach (2016) formed the definition of a strategy for implementing crisis management through the formation of a structural-logical scheme for choosing crisis management for agricultural enterprises, which included preventive, reactive, situational and "manual" anti-crisis management. If we talk exclusively about engineering enterprises, then, for example, N. Ershova (2008), proposed several strategic directions of the anti-crisis strategy: a reduction strategy, a limited growth strategy, and a growth strategy.

To date, there is no holistic and practically confirmed method for assessing the level of financial security, the calculation of which would provide information on the need for anti-crisis management at a engineering enterprise, taking into account the specifics of their activities.

\section{Research model and Data}

In our opinion, the assessment of the level of financial security at which it is necessary to apply anti-crisis management in an enterprise should be holistic and based on indicators that allow you to fully reflect the current financial situation and take into account the specifics of the industry. For this, it is necessary to attract relevant experts in the field of engineering, whose experience and knowledge will allow the formation of the necessary groups of indicators and calculate the integral indicator, the results of which would signal the absence or necessity of applying anti-crisis management. 
In order to better display the algorithm for assessing the financial security of an enterprise, in which it is necessary to apply anti-crisis management, we will construct a schematic map on which we distinguish three main levels: organizational and preparatory, evaluating and the level of use of the results (Fig. 1).

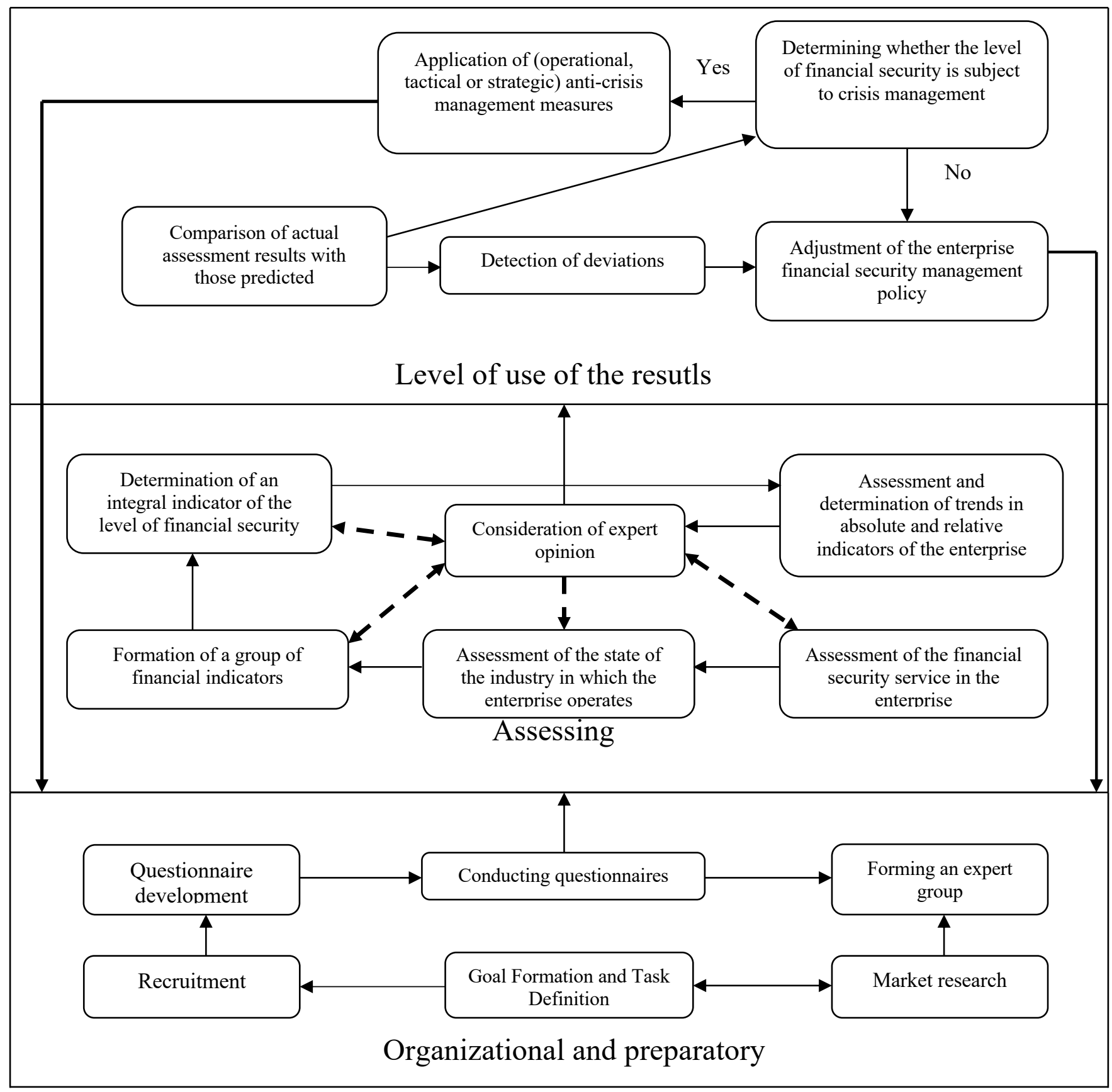

Figure 1. Schematic map of a multi-level algorithm for assessing the level of financial security
at which it is necessary to apply anti-crisis management in an enterprise

Source: developed by authors

To calculate the integral indicator, it is necessary to form a group of indicators that fully reflect the financial condition of the enterprise and determine the current level of financial security: "Desired", "Acceptable", "Recommended", "Allowable"; "Pre-crisis"; "Crisis". The level of 
financial security established by us will allow the management of enterprises to better understand when there is a need for the application of anti-crisis management.

\section{Results}

To establish the main indicators and their threshold values, at which the threat of a financial crisis at engineering enterprises, and there is a need for crisis management, we conducted a survey involving experts working in this field and are leading experts in the matter of financial security of the enterprise .

To conduct the survey, experts from leading regions in the field of engineering in Eastern Europe were elected. A total of 20 experts were selected from leading engineering enterprises.

For communication with experts, direct and remote contact methods were chosen. The frequency of the survey was one-time.

To assess the level of financial security of the enterprise, at which it is necessary to apply anti-crisis management, it is necessary to establish a number of indicators, it is better to reflect the financial condition and deterioration of which signal a crisis development. One of the questions for the respondents was to choose indicators of this kind, the values of which, they believe, best reflect the state of financial security of the engineering industry enterprise. The results made it possible to single out the best of all the financial indicators we listed, and we again sent the respondents a list of financial indicators, we selected according to the results of the survey, in order to obtain their final consent.

It is worth noting that all the indicators presented in the questionnaire for the survey of experts are a list formed as a result of summarizing a large number of financial indicators, they were found in scientific works of leading scientists in the field of assessing the level of financial security of an enterprise.

In Fig.2, you can see the list of financial indicators that better reflect the financial condition and level of financial security of the enterprise and whose decline may signal a crisis development, formed after its ugly approval by the respondents.

The coefficient of maneuverability of own funds Coefficient of financial stability Autonomy coefficient Product profitability Return on equity Return on assets Accounts payable turnover ratio Accounts receivable turnover ratio

Asset turnover ratio Absolute liquidity ratio Quick ratio Number of respondents who selected Total liquidity ratio a financial indicator

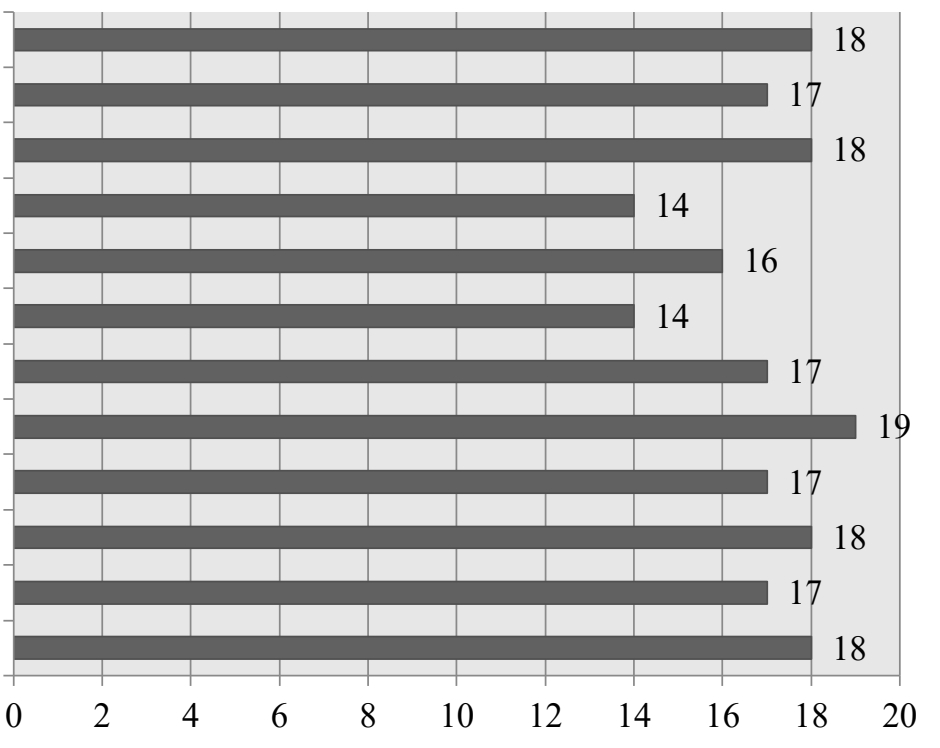

Figure 2. A list of key financial indicators has been compiled that will be used to assess the level of financial security at which it is necessary to apply anti-crisis management at the enterprise

Source: developed by authors 
In our opinion, not only are the groups of indicators formed above that will make it possible to fully assess the current state of financial security at the enterprise, it is necessary to pay attention to high-quality financial indicators. We have formed a group of "quality indicators", which include:

1. Payment discipline. Demonstrates the level and quality of the enterprise fulfilling its obligations to creditors or other persons.

2. The effectiveness of accounting and analytical support. More than once, in the first section it was established how key information support plays in the system of ensuring financial security and anti-crisis management, therefore, assessing the level of effectiveness of accounting and analytical support will assess the level of information support at the enterprise.

3. Interaction with counterparties. Having assessed the level of interaction of the enterprise with contractors, it is possible to more broadly assess the level of financial security, since a negative level of business relations can significantly affect the image and activity of the enterprise and become a serious threat to its development.

Having established and agreed upon the main indicators that will be used to determine the level of financial security at the enterprise, at which anti-crisis management is necessary, we asked respondents to fill out a table, in which it was necessary to enter indicators in the environment and set their threshold value for subsequent levels of financial safety: "Desired", "Acceptable", "Recommended", "Allowable"; "Pre-crisis"; "Crisis". It should be noted that at each of the presented levels of financial security, the enterprise should apply preventive measures to prevent crisis development or its deterioration but conditionally, we can say that, for example, at this level of "crisis" it is necessary to apply operational anti-crisis measures when at the "desired" level, it is enough to exercise proper control over compliance with such a high level.

The key place in the levels of financial security that we offer is played by the "Pre-crisis" one, and it is this level that should signal a significant threat of the onset of the financial crisis. In addition, if an enterprise received an "acceptable" level based on the results of the assessment, then we can talk not about urgent, but the need for anti-crisis measures. Based on the results of expert assessment (the respondents during the survey indicated that financial indicators were prioritized for those that, in their opinion, have the greatest impact on assessing the level of financial security of an enterprise to the lowest), we determined the proportion of financial indicators separately and of the groups to which the data relate indicators. The proportion of financial indicators for assessing the level of financial security of enterprises, is shown in Table 1.

\section{Table 1. - The proportion of current financial indicators to assess the level of financial security of the enterprise}

\begin{tabular}{|c|c|c|c|c|c|c|c|c|c|}
\hline $\begin{array}{l}\text { Indicator } \\
\text { (l) }\end{array}$ & $\begin{array}{c}\text { Weig } \\
\text { ht } \\
\left(w_{l i}\right)\end{array}$ & $\begin{array}{c}\text { Indicator } \\
\text { (r) }\end{array}$ & $\begin{array}{c}\text { Weight } \\
\left(w_{\text {ri }}\right)\end{array}$ & $\begin{array}{c}\text { Indicator } \\
\text { (p) }\end{array}$ & $\begin{array}{c}\text { Weight } \\
\left(w_{p i}\right)\end{array}$ & $\begin{array}{c}\text { Indicato } \\
\mathbf{r} \\
(\mathbf{s})\end{array}$ & $\begin{array}{c}\text { Weight } \\
\left(\mathbf{w}_{\mathrm{si}}\right)\end{array}$ & $\begin{array}{c}\text { Indicators } \\
\text { (q) }\end{array}$ & $\begin{array}{l}\text { Weigh } \\
t\left(w_{\text {qi }}\right)\end{array}$ \\
\hline $\begin{array}{l}\text { Total } \\
\text { liquidity } \\
\text { ratio }\end{array}$ & 0,4 & $\begin{array}{l}\text { Asset } \\
\text { turnover } \\
\text { ratio }\end{array}$ & 0,5 & $\begin{array}{l}\text { Return on } \\
\text { assets }\end{array}$ & 0,45 & $\begin{array}{c}\text { Autonom } \\
\text { y } \\
\text { coefficie } \\
\text { nt }\end{array}$ & 0,5 & $\begin{array}{l}\text { Payment } \\
\text { discipline }\end{array}$ & 0,3 \\
\hline $\begin{array}{l}\text { Quick } \\
\text { ratio }\end{array}$ & 0,4 & $\begin{array}{c}\text { Accounts } \\
\text { receivable } \\
\text { turnover } \\
\text { ratio }\end{array}$ & 0,25 & $\begin{array}{l}\text { Return on } \\
\text { equity }\end{array}$ & 0,35 & $\begin{array}{l}\text { Coefficie } \\
\text { nt of } \\
\text { financial } \\
\text { stability }\end{array}$ & 0,35 & $\begin{array}{c}\text { The } \\
\text { effectiveness } \\
\text { of } \\
\text { accounting } \\
\text { and } \\
\text { analytical } \\
\text { support }\end{array}$ & 0,4 \\
\hline $\begin{array}{l}\text { Absolute } \\
\text { liquidity } \\
\text { ratio }\end{array}$ & 0,2 & $\begin{array}{l}\text { Accounts } \\
\text { payable } \\
\text { turnover } \\
\text { ratio }\end{array}$ & 0,25 & $\begin{array}{c}\text { Product } \\
\text { profitabilit } \\
y\end{array}$ & 0,2 & $\begin{array}{c}\text { The } \\
\text { coefficie } \\
\text { nt of } \\
\text { maneuver } \\
\text { ability of } \\
\text { own } \\
\text { funds }\end{array}$ & 0,15 & $\begin{array}{l}\text { Interaction } \\
\text { with } \\
\text { counterpartie } \\
\text { s }\end{array}$ & 0,3 \\
\hline
\end{tabular}


So, according to the results of an expert assessment, research of scientific literature on the subject of other models of assessing financial security, it allowed to collect and use the results of the study to form a model for assessing the level of financial security at which it is necessary to apply anti-crisis management at a engeeniring enterprise (Fig.5).

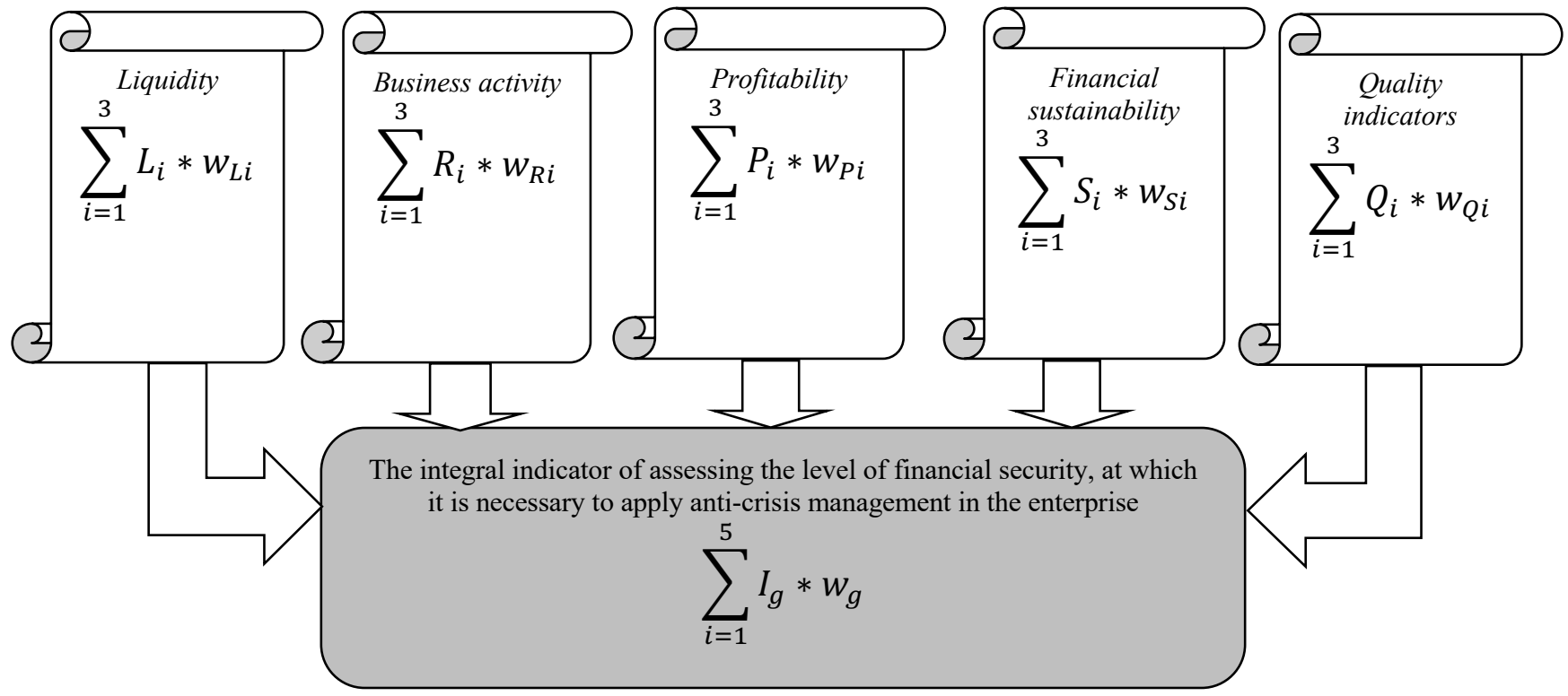

Figure 5. An integral indicator of assessing the level of financial security at which it is necessary to apply anti-crisis management at the enterprise

Source: developed by authors

Our proposed model for assessing the financial security of an enterprise synthesizes a set of basic parameters of the financial activity of an enterprise and forms an information basis for making effective management decisions in the process of implementing anticrisis measures.

The integral index can reach values from 0 to 1 . In this interval, we formulate at what values it is necessary to apply anti-crisis management, and when not (Fig.4). 


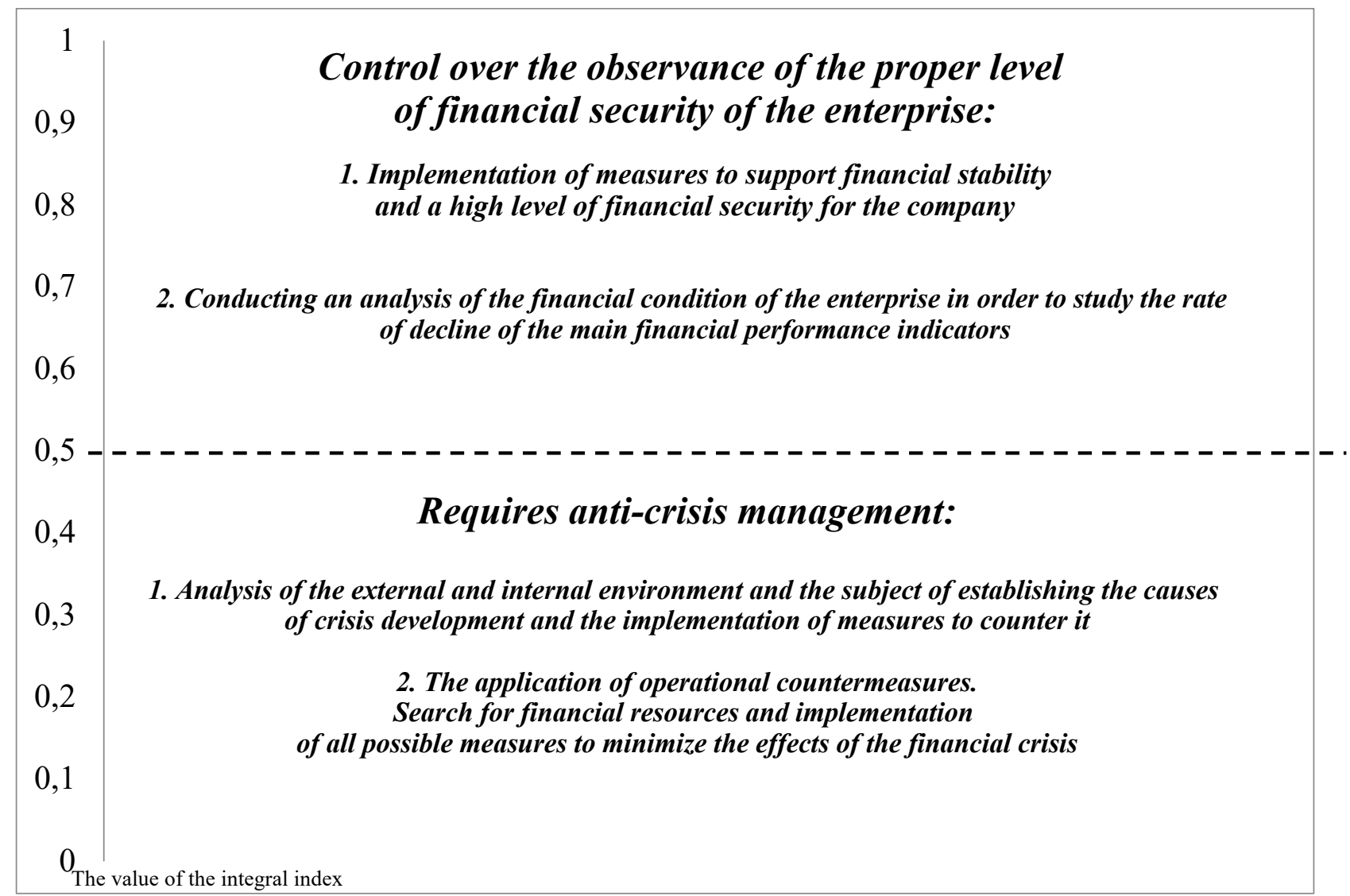

Figure 4. The scale of the integral indicator of assessing the level of financial security at which it is necessary to apply anti-crisis management in the enterprise

Source: developed by authors

When the value of the integrated indicator for assessing the level of financial security of an enterprise reaches below 0.5 , then it is necessary to apply various kinds of anti-crisis management measures: strategic, tactical or operational.

\section{Conclusions}

Thus, summarizing the results of the study, it can be argued that our proposed algorithm and a model for assessing the level of financial security allows us to most effectively reflect the need for anti-crisis management at the enterprise and takes into account the specifics of the selected industry (engineering). So, the scientific and practical approach that we have formed can form the basis for managing financial security of engineering enterprises and will allow us to identify the signs of crisis development as quickly as possible in order to respond in a timely manner.

In the future, it is necessary to put into practice the proposed model at individual enterprises in Eastern Europe.

\section{References}

Aref'eva O., Prokhorova Y. (2008) Bankruptcy probability diagnostics by means of identification of machine-building enterprises depending on the types of financial crisis. Visn. Economics of Transport and Industry: Coll. Research Practice Art. № 21. pp. 76-81.

Blank I. (2005) Crisis financial management of the enterprise. K .: Elga: Nika Center, 672 p.

Goryacheva K. (2003) Financial security of the enterprise, essence and place in the system of economic security. Economist. № 8. pp. 65-67. 
Prokhorova $\mathrm{Yu}$. (2008) Anti-Crisis financial management of the enterprise. Manuscript. Dissertation for the degree of Candidate of Economic Sciences in specialty 08.00.04 Economics and Management of Enterprises (by types of economic activity). European University, Kyiv.

Kovalev A. (1998) Analysis of financial condition and forecasting bankruptcy. St. Petersburg: Audit Azhur. 163 p.

Plastun O. (2007) Qualitative diagnostic methods in the financial security of business entities. Bulletin of the Ukrainian Academy of Banking. No. 1 (22). pp. 40-44.

Ligonenko L. Anti-Crisis management of the enterprise: textbook. K.: KNEU, 824 p.

Mandzinovskaya Kh, Stangret A. (2016) Financial security of engineering enterprise: Methodical principles of formation and maintenance: monogr. Lviv: Ukr. Acad. printing. $226 \mathrm{p}$.

Demchenko I. (2010) Strategic management of financial security of the entity. Finance, banks, investments. №2. P.43-46.

Gasanov S., Stangret A., Kotlyarevsky Y. (2012) Crisis Corporate Governance: Theoretical and Case Studies. K .: DNNU “Acad. Finn. Management”, 301 p.

Ali Lami Hyder Muhsin Abdulaziz (2016) Formation of organizational and economic mechanism of enterprise crisis management. The dissertation on competition of a scientific degree of the candidate of economic sciences. Lugansk National Agrarian University. Kharkiv. 196 p.

Golovach K. (2016) Formation of a crisis management mechanism in agricultural enterprises. The dissertation for the degree of candidate of economic sciences, specialty 08.00 .04 - economics and enterprise management. Zhytomyr National Agroecological University. Zhytomyr, 249 p.

Ershova N. Yu. (2009) Diagnostics in the system of crisis management of machine-building enterprises. -Dissertation for the Candidate Degree in Economics, specialty 08.00.04 - Economics and Management of Enterprises (by type of economic activity). National Technical University "Kharkiv Polytechnic Institute". Kharkiv. 